\title{
B1 düzeyi ders materyallerinin söz varlığının ve B1 düzeyi öğrencilerin yazılı söz varlığının çeşitli değişkenler açısından derlem tabanlı incelenmesi
}

\section{Ramazan ŞiMŞEK ${ }^{1}$}

\begin{abstract}
APA: Şimşek, R. (2020). B1 düzeyi ders materyallerinin söz varlığının ve B1 düzeyi öğrencilerin yazılı söz varlığının çeşitli değişkenler açısından derlem tabanlı incelenmesi. RumeliDE Dil ve Edebiyat Araştırmaları Dergisi, (Ö7), 152-171. DOI: 10.2900o/rumelide.808315.
\end{abstract}

$\ddot{O} \mathbf{z}$

Yabancı dil eğitimi açısından derlem tabanlı çalışmalarının önemi giderek artmaktadır. Derlem tabanlı çalışmalar aracılığı ile dil eğitiminde öğretilen kelimelerin öncelikleri uluslararası kıstaslar çerçevesinde belirlenmektedir. Yazılı ve sözlü birçok tabakadan oluşan derlemler ve alt derlemler hem öğretici hem de öğrenci için sürecin verimliliğini artırmaktadır. Yabancı dil olarak Türkçe öğretiminde genellikle ders materyallerinin söz varlı̆̆ı üzerine odaklanılmaktadır. Öğrenen bireylerin söz varlığı da bu süreçte araştırmacılar için üzerinde durulması gereken alanlardandır. Yabancı dil olarak Türkçe öğrenen bireylerin yazılı ya da sözlü söz varlı̆̆ı hem mevcut durumu görmek için hem de sıklık listeleri ile kıyaslamalar yapabilmek için gözetilmektedir. Ders kitapları bünyesinde yer alan metinler öğretim programı ve öğretici için çatı konumundadır. Bu çalışmada da Yabancı dil olarak Türkçe öğrenen B1 düzeyi öğrencilerin yazılı söz varlığı, derste kullanılan materyallerin okuma metinlerinin söz varlığı ve Aksan vd. (2017) derlem tabanlı çalışması araştırmanın odak noktasını oluşturmaktadır. Araştırma çerçevesinde 6 haftalık B1 kuru süresince 21 öğrenciye 7 farklı kompozisyon yazdırılmıştır. Akabinde öğrencilerin yazılı söz varlı̆̆ının belirlenmesi için bu kompozisyonlar bilgisayar ortamına aktarılmış; kullanılan ders kitabındaki okuma metinleri ilgili aşamalardan geçirilerek söz varlığının belirlenmesinde kullanılacak yazılım için uygun hale getirilmiştir. Ders kitabının söz varlığı ve öğrencilerin yazılı anlatımlarının söz varlığında en sık kullanılan 500 kelime, sözcük türleri bakımından en sık kullanılan 500 kelime Aksan’ın (2017) çalışması ile kıyaslanmış, benzerlik düzeyleri tespit edilmiştir. En sık kullanılan kelimeler bakımından Aksan (2017) derlem tabanlı çalışması ile ders materyalinin söz varlı̆̆ının benzerlik düzeyi bakımından istenen ideal düzeyde olmadığı saptanmıştır.

Anahtar kelimeler: Derlem, söz varlı̆̆ı, okuma metinleri, yazılı anlatım

\section{B1 level textbooks of vocabulary, B1 level students of written vocabulary in terms of various variables based on review}

\begin{abstract}
The importance of corpus-based studies is gradually increasing in terms of foreign language education. The priorities of the words taught in language education are determined within the framework of international criteria through corpus-based studies. Corps and subcollections consisting of many layers such as written texts and speeches increase the efficiency of the process for both the instructor and the student. Teaching Turkish as a foreign language generally focuses on the vocabulary of course materials. The vocabulary of learning individuals is one of the areas that should be focused on for researchers in this process. Written or oral vocabulary of individuals
\end{abstract}

Öğr. Gör. Dr., Nevşehir Hacı Bektas Veli Üniversitesi, TÖMER (Nevşehir, Türkiye), ramazansimsek@nevsehir.edu.tr, ORICID ID: oooo-0002-8295-8903 [Makale kayit tarihi: 23.08.2020-kabul tarihi: 20.10.2020; DOI: 10.2900o/rumelide.808315] 
learning Turkish as a foreign language is observed both to see the current situation and to make comparisons with frequency lists. The texts within the textbooks are the roof for the curriculum and the instructor. In this study, the written vocabulary of B1 level students learning Turkish as a foreign language, the vocabulary of the reading texts of the materials used in the lesson and Aksan (2017) corpus-based study constitute the focus of the study. 7 different compositions were written to 21 students during the 6-week B1 course. Subsequently, these compositions were transferred to computer environment in order to determine the students' written vocabulary; The reading texts in the textbook used have been made suitable for the software to be used in determining the vocabulary by passing through the relevant stages. The most frequently used 500 words in the vocabulary of the textbook and the written expressions of the students were compared with the work of Aksan (2017), the 500 words most frequently used in terms of word types, and their level of similarity was determined. In terms of the most frequently used words, it was determined with the corpus-based study of Aksan (2017) that the vocabulary of the course material was not at the desired ideal level in terms of similarity level.

Keywords: Corpus, vocabulary, reading texts, written expression

\section{Giriș}

Tarihsel süreç içerisinde doğrudan ya da dolaylı olarak iletişim kuran insanoğlunun en büyük bildirişim aracı dildir. Dil, insanların düşündüklerini ve duyduklarını bildirmek için kelimelerle veya işaretlerle yaptıkları anlaşma, lisandır (Türkçe Sözlük, 2005: 526). Dil, bir toplumda düşünce duygu ve isteklerin ses ve anlam yönünden ortak olan öğeler ve kurallardan yararlanılarak başkalarına aktarılmasını sağlayan çok yönlü, çok gelişmiş bir dizgedir (Aksan, 1977: 55).

Dil aksiyonları içinde iletişimi yönlendiren ve semantik yükü çeken temel faktörlerden en önemlisi kelime ya da sözcüktür. Sözcük, anlamı ya da görevi bulunan, çekim ekleriyle işlenmeye hazır taban şeklinde tanımlanabilir (Baş, 2011). İnsan, sosyal bir varlık olması sebebiyle ifade etmek istediklerini sözcükler aracılığıyla anlatır (Yllmaz ve Doğan, 2014). Anlama ve anlatma becerilerinin etkin kullanılması ile sözvarlığının zenginliği arasında yakın bir ilişki mevcuttur (Karatay, 2007: 143). Sözcük ve cümle bilgisi, çok temel bir seviyede okuma için kesinlikle önemlidir (Grabe, 1991: 380) çünkü sözcük bilgisi ile okuduğunu anlama arasında kuvvetli bir bağlantı mevcuttur (Matsuoka ve Hirsh, 2010: 56). Alıcı ve verici beceriler açsından köprü görevi gören ve semantik yükü çeken sözcük temel dil becerilerini işler hale getirmektedir.

Dil öğretiminin temel amacı; öğrenende, dört temel beceri olarak adlandırılan dinleme, konuşma, okuma ve yazma becerilerini geliştirmektir. Bu hedefler doğrultusunda her eğitim-öğretim ortamında olduğu gibi dil öğretimi alanında da öğretimi kolaylaştırmak ve kalıcılığı sağlamak adına çeşitli materyallerden faydalanılır. Öğretim materyali, öğrencilerin öğrenmesi, öğretmenin etkin bir öğretme sağlayabilmesi için özel olarak hazırlanmış öğretme-öğrenme yardımcılarıdır (Demirel, 2005: 7) Ders kitapları öğrenme materyalleri içinde hem öğretmen için hem de öğrenci için anahtar konumundadır. Ders kitabı bünyesinde yer alan metinler aracılığı ile eğitim-öğretim sürecinin planlanması, kontrol edilmesi, toplumsal ve kültürel kodların hedef kitleye aktarılması sağlanmaktadır. Bu çerçevede ders kitabında yer alacak metinlerin taşıması gereken genel özellikler bulunduğu gibi söz varlığı açısından da belirli standartlar sahip olması gerekmektedir. Söz varlığı, metinlerin düzeye göre niteliğini, semantik gönderim düzeyini belirleyen temel faktör olarak karşımıza çıkmaktadır. Aksan’a (2015) göre sözvarlı̆̆ı, yalnızca dilin sözcüklerini değil deyimlerini, kalıp sözlerini, kalıplaşmış sözlerini, 
B1 level textbooks of vocabulary, B1 level students of written vocabulary in terms of various variables based on review / R. Şimşek (pp. 152-171)

atasözlerini, terimlerini ve çeşitli anlatım kalıplarını kapsayan bir bütündür. Bu terimle anlatılan varlık, o dili konuşan ulusun maddi ve manevi kültürünü, dünya görüşünü, yaşam koşullarını ve deneyimlerini de yansitır (Aksan, 2014a: 13).

Sözcük sıklığı, bir sözcüğün kullanılma oranı, frekans olarak tanımlanabilir (Aydın, 2015). Thorndike de 1921 yılında yayımladığı The Teacher's Word Book (Öğretmenin Sözcük Kitabı) adlı eserinin girişinde sıklık tabirinin "Sözcük ne sıklıta kullanılıyor?" sorusunun cevabı olduğunu ifade etmektedir. (Akt. Armut. Coxhead, 2000: 217). Eğitim ve öğretim süreçleri açısından değerlendirildiğinde en sık kullanılan materyal ders kitabı olup içerik ve nitelik açısından değerlendirilirken söz varlığı da değerlendirme kıstasları içinde öne çıkmaktadır.

Yabancı dil öğretiminde de "Sözcük bilgisi dört temel dil becerisinin ve dil bilgisinin tamamlayıcısı niteliğindedir ve bu alanların geliştirilmesinde temel rol üstlenir.” (Kurudayığlu ve Dölek, 2019: 30). Türkçeyi yabancı dil olarak öğrenenler açısından düşünüldüğünde ise "Öğrenenlerin sözcük öğrenme ihtiyaçları ana dili Türkçe olanlara göre daha farklıdır ve daha çok çaba gerektirir." (Karatay, 2020: 256). Ana dili eğitiminde olduğu gibi yabancı dil eğitiminde de temel söz varlığı öğrencinin öğrenme motivasyonu, başarabilme iştiyakı gibi faktörler dilin işlevsel kullanımı açısından önem arz etmektedir. Hedef dilin temel söz varlığıyla ilgili oluşturulacak listeler öğrencinin sürece yönelik önyargılarını kırıp temel dil becerilerini etkin olarak kullanmasını sağlayacaktır. Bu kapsamda hedef dili başlangıç düzeyinde öğrenen bir birey ile ileri düzeyde öğrenen birey arasında öğrenen ihtiyaçları farklılık gösterecek; hedef kelime listesi ve söz varlığı da bu farklılıklar arasında yer alacaktır.

Yazınsal metinlerin yaşamla olan ilişkileri incelendiğinde yazınsal ürünlerde yaşam gerçekliğinin, insanlık durumunun, yazarın iç dünyasında kurularak anlatıldığı görülür. Bu bakımdan yazınsal metinlerin insanın ve toplumun farklı yönleriyle kavranmasında önemli bir payı vardır. Yabancı dille yazılmış yazınsal metinlerde de o dilin dünyasının, bize göre yabancı olan yaşamın yansımasını bulmak mümkündür (Polat, 2012). Yapılan değerlendirmeler ışığında yabancı dil eğitimi için hazırlanan ders kitapları ve ders kitapları bünyesinde yer alan metinler, metin içerikleri hedef dili öğrenen bireylerin düzeyine, ihtiyaçlarına, dili kullanım amaçlarına uygun olarak hazırlanması ihtiyacı öne çlkmaktadır. Bu bağlamda öğrenilmesi gereken kelimelerin söz varlığı açısından zengin seçkilerden faydalanılarak belirlenmesi; dil öğrenen kitlenin söz varlı̆̆ı da sürecin verimliliği açısından karşılaştırmalı olarak ele alınmalıdır. Teknoloji ve bilişim çerçevesinde dil eğitimi çalışmalarında bu ihtiyacı derlem, derlem dilbilim çalışmaları gidermektedir.

Söz varlı̆̆ı çalışmalarının son yıllarda daha geniş kapsamlı derlem dilbilim uygulamaları ile gerçekleştirildiği bilinmektedir. Türkçeye "derlem” olarak aktarılan bu terim Latince kökenli bir sözcük olup vücut anlamına gelmektedir ve sözcüğün çoğulu olan "corpora” Latince çoğul ekleriyle oluşturulmuştur. McEnery ve Hardie (2011: 32) derlemi "İncelenecek olan dil değişkesini en üst düzeyde temsil edici güce sahip, makine tarafından okunabilen ve belli sınırları olan metin bütünü" şeklinde tanımlamışlardır. Weisser (2016: 13) derlemi, "Belli bir dilsel çalışmanın amacı ve kapsamına bağlı olarak şekillendirilen özel tasarım ölçütleri temel alınarak ve dilsel bir incelemede kullanılmak üzere seçilen sözlü ya da yazılı metinlerin derlemesi” olarak tanımlamıştır. Gries (2009: 7), derlemi, "Doğal bir iletişim ortamında üretilen, makine tarafından okunabilen (yazılı ya da sözlü) metinlerin derlemesi” olarak tanımlamıştır. Bu metinler ise, belli bir dil değişkesi, dil kesiti ya da yazınsal tür açısından temsil edici ve dengeli olmaları ile dilbilimsel incelemelerinin yapılması amacıyla derlenir. Dash (2008: 27) ise derlemi, "dilbilimin tüm alanlarında araştırma, betimleme, uygulama ve inceleme yapmak amacıyla istatistiksel olarak örneklemi çıkarılmış dilsel bir veri tabanı” şeklinde 
tanımlamaktadır. Elena (2001: 55) derlemi, "otomatik ya da yarı otomatik işleme ve incelemeye uygun olan gerçek metinlerin bilgisayarda işlenmiş kümesi" olarak tanımlar. Derlem için yapılan tanımlardan hareketle; özel bir amaç için bir araya getirilen metinlerin bilgisayar ortamına aktarılarak metin türü, kelime yapısı, sıklık, bağlam analizi gibi işlemler için elektronik ortamda işlenmesiyle ilgili vurgunun öne çıktığı görülmektedir. Derlem için temel veriler yazılı ve sözlü metinlerdir. Bu metinler aracılığı ile dil eğitimi için ihtiyaca göre öncelikli, tematik içerikler oluşturulabilir.

Bir dilin, kullanıldığ $ı$ karakteristik ortamlarından biri de yazın dilidir. Yazın dili özelliği gereği o dilin genel yapısını betimlemek için önemli veriler sağlar. Öte yandan, yazı dili araştırma nesnesi olarak ölçünlü ve araştırmacılar için kolay erişilebilirdir. Bir derlemden bu anlamda derlenen verilerin güvenilirliği yapılacak betimlemenin de güvenilirliği anlamına gelmektedir (Özkan, 2013). Derlemin tasarımında, örneğin, içerikte yer alan metinlerin türü, metin sayısı, belirli metin parçalarının seçimi, metin parçaları arasından örneklem seçimi, örneklemin genişliği vb. tasarımın bilinçli yapılıp yapılmadığının ölçüsüdür (Sampson vd. 2005: 174). Dil öğretim sürecinde yazılı kaynaklar açısından ders kitapları ihtiyaçlar ve hedefler bakımından temel materyaller arasında yer alıp Türkçe öğretiminde de aynı öneme sahiptir. Türkçenin yabancı dil olarak öğretiminde kullanılan ders kitapları sıklık listeleri açısından farklılıklar gösterebilmektedir. Alan yazın açısından değerlendirildiğinde Türkçenin yabancı dil olarak öğretiminde sıklık listelerinin genellikle sezgisel olarak belirlendiği gözlemlenmektedir.

20. yüzyılın başında Avrupa'da yapılmaya başlanan derlem tabanlı çalışmalara söz varlığı, sıklık çalışmalarının temelini oluşturmaktadır. Derlem tabanlı çalışmalar son yıllarda Türkiye'de de ilgi çekici çalışma alanlarının başında gelmektedir. Türkçe için yayımlanmış derlem temelli en kapsamlı sıklık listesi Aksan vd. (2017) tarafından yayımlanan A Frequency Dictionary of Turkish (Türkçe Sıklık Sözlüğü) olarak bilinmektedir. Özkan (2010), bilgisayar aracıllğıyla dile ait olan verilerin işlenmesinin yöntemsel olarak ortaya çıkardığı olumlu sonuçların dilbilimin çalışma alanlarında belirgin olarak görüldüğünü; zamanla yaygınlaşma alanını genişleten bilgisayarlı dil çalışmalarının derlem dilbilim, sözlükbilim, biçimbilim, sesbilim, makineli çeviri, anlambilim vb. dilbilim alanlarında hissettirdiğini ifade etmiştir. Bu çalışmada da yabancı dil olarak Türkçe öğrenen bireylerin yazılı söz varlı̆̆ı, aynı düzeyde hazırlanmış ders kitabının söz varlığından faydalanılarak oluşturulmuş sıklık listeleri, sözcük türlerine göre oluşturulmuş sıklık listeleri, Aksan vd. (2017) derleme dayalı yaptığı sıklık listesi karşlaştırılarak ortak söz varlı̆̆ına yönelik bulgular elde edilmiştir.

\section{Yöntem}

\section{1. Çalışmanın deseni}

Yabancı dil olarak Türkçe öğretiminde kullanılan B1 düzeyi ders kitaplarının ve aynı düzeydeki öğrencilerin söz varlı̆̆ının, sözcük türlerine göre oluşturulan sıklık listelerinin incelendiği bu çalışmada betimsel bir araştırma olup tarama modeli benimsenmiştir. "Tarama modelleri, geçmişte ya da halen var olan bir durumu var olduğu şekliyle betimlemeyi amaçlayan araştırma yaklaşımlarıdır. Araştırmaya konu olan olay, birey ya da nesne, kendi koşulları içinde ve olduğu gibi tanımlanmaya çalışılır. Onları herhangi bir şekilde değiştirme, etkileme çabası gösterilmez" (Karasar, 2010: 77).

\section{2. Çalışma grubu}


B1 level textbooks of vocabulary, B1 level students of written vocabulary in terms of various variables based on review / R. Şimşek (pp. 152-171)

Araştırmanın çalışma grubunu 2019-2020 eğitim öğretim yllında Nevşehir Hacı Bektaş Veli Üniversitesi TÖMER'de B1 düzeyinde Türkçe eğitimi alan 15 farklı ülkeden 21 öğrenci ve Türkçeye Yolculuk B1 düzeyi ders kitabı ile çalışma kitabının okuma metinleri oluşturmaktadır.

Tablo 1. Çalışma Grubunun Uyruk Bilgisi

\begin{tabular}{ll}
\hline Ülke & Öğrenci Sayısı \\
\hline Afganistan & 4 \\
Misır & 2 \\
Yemen & 2 \\
Gine & 2 \\
Filistin & 1 \\
Pakistan & 1 \\
Nijer & 1 \\
Irak & 1 \\
Etiyopya & 1 \\
Fildişi & 1 \\
Kolombiya & 1 \\
Bangladeş & 1 \\
Somali & 1 \\
Moritanya & 1 \\
Kazakistan & 1 \\
Toplam & 21 \\
\hline
\end{tabular}

\subsection{Verilerin analizi}

Araştırma kapsamında incelenen yabancı dil olarak Türkçe öğretiminde kullanılan Türkçeye Yolculuk B1 düzeyi ders kitabı ve çalışma kitabı bilgisayar ortamına aktarılmış, OCR yazılımı ile kitaplarda yer alan okuma metinleri sayısallaştırılıp UTF-8 kod dönüşümünden geçirilerek veri seti oluşturulmuştur. Öğrencilerin yazılı söz varlı̆̆ının tespiti için 2019-2020 eğitim öğretim Nevşehir Hacı Bektaş veli Üniversitesi TÖMER bünyesinde B1 kurunda eğitim alan her öğrenciye 7 farklı konuda kompozisyon yazdırılmış; bu kompozisyonlar bilgisayar ortamına aktarılmıştır. Kur süresince kullanılan Türkçeye Yolculuk B1 düzeyi ders kitabı ve çalışma kitabı okuma metinlerinin söz varlığı ve en sık kullanılan kelimeler WordsmithTools 7.o yazılımı ile tespit edilmiştir. Her kitap tema, içerikleriyle ilişkili olarak her öğrenciye yazdırılan 7 farklı kompozisyonun söz varlığı, en sık kullanılan kelimeler ilgili yazılımla tespit edilmiş; B1 düzeyi ders kitabının söz varlığı ve öğrencilerin kompozisyonlarından oluşan veri setinin söz varlığı tespit edilmiştir. Akabinde her kitabın kelime listesi ve kitaplarda ortak olarak kullanılan kelimelerin listesi Aksan vd. (2017) tarafından derlem tabanlı yapılan Türkçede en slk kullanılan 500 kelime, en sık kullanılan sıfatlar ve fillerle aynı yazılım aracılı̆̆ıyla karşılaştırılarak incelenmiş, ortaklık düzeyleri tespit edilmiştir. 
Şekil 1. Wordsmith Tools Programının Ara yüzü

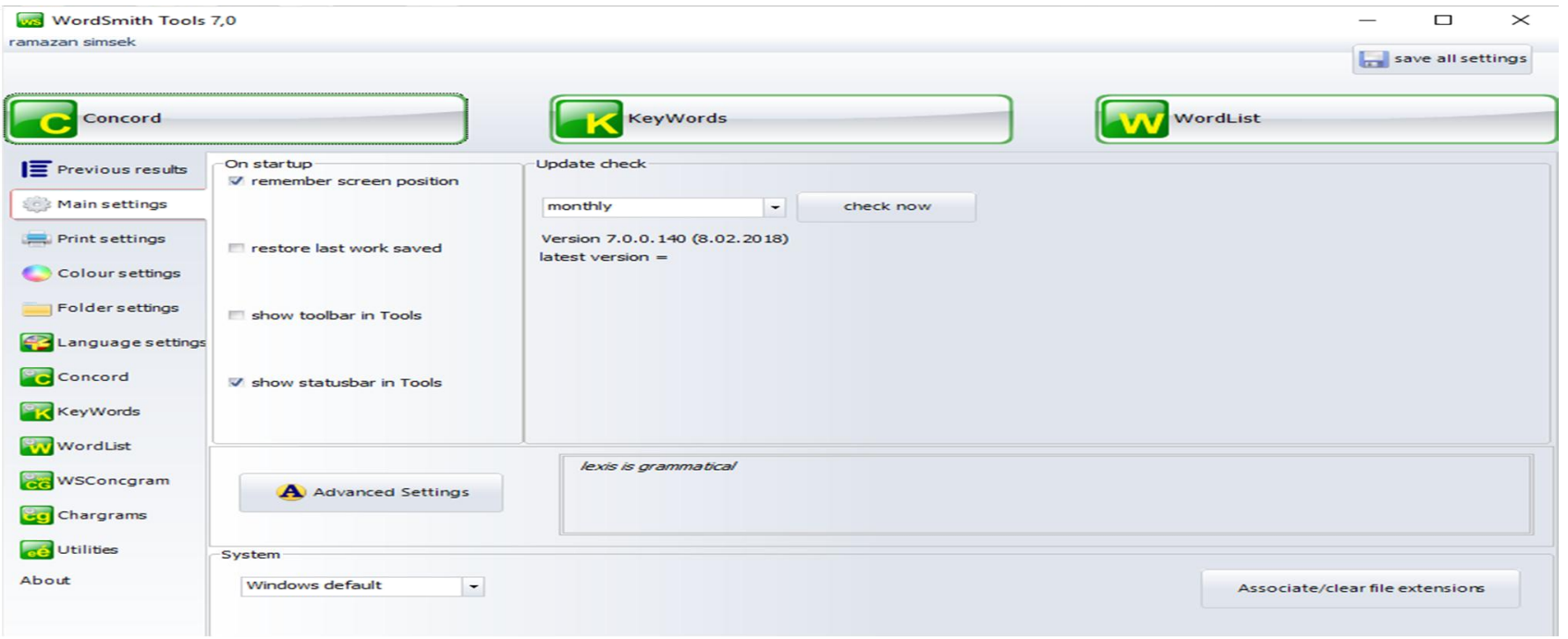

\section{Bulgular ve yorumlar}

\section{Türkçeye Yolculuk B1 düzeyi ders kitabı ve çalışma kitabının söz varlığına yönelik bulgular}

Türkçeye Yolculuk B1 Düzeyi Ders Kitabının sınıf Türkçe ders kitabı derlem tabanlı inceleme süreci için yöntem kısmında ifade edilen süreçlerden geçirilerek analiz sürecinde kullanılacak yazılım veri tabanına uygun hale getirilmiştir.

Tablo 2. Türkçeye Yolculuk B1 Düzeyi Ders Kitabının Söz Varlığına Yönelik Bulgular

\begin{tabular}{lllll}
\hline $\begin{array}{l}\text { Kitaplarda } \\
\text { Incelenen } \\
\text { Metin Sayıs }\end{array}$ & $\begin{array}{l}\text { Toplam } \\
\text { Kelime sayısı } \\
\text { (Token) }\end{array}$ & $\begin{array}{l}\text { Farklı Kelime } \\
\text { Sayıs(Type) }\end{array}$ & $\begin{array}{l}\text { Her Metne } \\
\text { düşen farklı } \\
\text { kelime } \\
\text { sayısı }\end{array}$ & $\begin{array}{l}\text { Kelime Hazine } \\
\text { Katsayıs(Type/Token) }\end{array}$ \\
\hline 60 & 14447 & 5939 & 98 & 0,41 \\
\hline
\end{tabular}

Türkçeye Yolculuk B1 düzeyi ders kitabı ve çalışma kitabında 60 metin incelenmiş; bu metinlerin söz varlığı (token) 14447 kelimeden oluştuğu tespit edilmiştir. Ders kitabı bünyesinde farklı kelime sayısı (type) ise 5939 olarak tespit edilirken her metne düşen farklı kelime sayısı 98 olarak saptanmıştır. Toplam kelime sayısının farklı kelime sayısına oranı 0.41 ya da \% 41 olarak ifade edilebilir. $\mathrm{Bu}$ verilerden hareketle ders kitabı bünyesinde her 100 kelimeden 41'inin farklı olduğu tespit edilmiştir.

Türkçeye Yolculuk B1 düzeyi ders kitabında en sık kullanılan 100 kelime Tablo 2'de gösterilmiştir.

Tablo 3. Türkçeye Yolculuk Bı Düzeyi Ders Kitabında En Sık Kullanılan Kelimeler

\begin{tabular}{llllllll}
\hline No & Kelime & Frekans & $\mathbf{\%}$ & No & Kelime & Frekans & \% \\
\hline 1 & Bir & 337 & 2,30 & 51 & Bey & 19 & 0,13 \\
2 & Ve & 314 & 2,14 & 52 & Fazla & 19 & 0,13 \\
3 & Bu & 203 & 1,39 & 53 & İki & 19 & 0,13 \\
4 & Çok & 138 & 0,94 & 54 & İse & 19 & 0,13 \\
\hline
\end{tabular}


B1 level textbooks of vocabulary, B1 level students of written vocabulary in terms of various variables based on review / R. Şimşek (pp. 152-171)

\begin{tabular}{|c|c|c|c|c|c|c|c|}
\hline 5 & De & 132 & 0,90 & 55 & Saat & 19 & 0,13 \\
\hline 6 & $\mathrm{Da}$ & 124 & 0,85 & 56 & Size & 19 & 0,13 \\
\hline 7 & İçin & 102 & 0,70 & 57 & Spor & 19 & 0,13 \\
\hline 8 & İyi & 59 & 0,40 & 58 & Türkçe & 19 & 0,13 \\
\hline 9 & Daha & 58 & 0,40 & 59 & Biraz & 18 & 0,12 \\
\hline 10 & Ben & 56 & 0,38 & 60 & Devam & 18 & 0,12 \\
\hline 11 & İş & 56 & 0,38 & 61 & Diğer & 18 & 0,12 \\
\hline 12 & En & 50 & 0,34 & 62 & Görevli & 18 & 0,12 \\
\hline 13 & $\mathrm{Ne}$ & 50 & 0,34 & 63 & Müdür & 18 & 0,12 \\
\hline 14 & Sonra & 48 & 0,33 & 64 & $\mathrm{Ol}$ & 35 & 0,12 \\
\hline 15 & Her & 45 & 0,31 & 65 & Toplantı & 18 & 0,12 \\
\hline 16 & İle & 45 & 0,31 & 66 & Tüm & 18 & 0,12 \\
\hline 17 & Olarak & 45 & 0,31 & 67 & Var & 18 & 0,12 \\
\hline 18 & Olan & 36 & 0,25 & 68 & Ayrica & 17 & 0,12 \\
\hline 19 & Önce & 35 & 0,24 & 69 & Başarılı & 17 & 0,12 \\
\hline 20 & Var & 35 & 0,24 & 70 & Belli & 17 & 0,12 \\
\hline 21 & Gibi & 32 & 0,22 & 71 & Beslenme & 17 & 0,12 \\
\hline 22 & Veya & 32 & 0,22 & 72 & Çünkü & 17 & 0,12 \\
\hline 23 & Ama & 31 & 0,21 & 73 & $\mathrm{Ev}$ & 17 & 0,12 \\
\hline 24 & Hem & 31 & 0,21 & 74 & Hasta & 17 & 0,12 \\
\hline 25 & İlk & 31 & 0,21 & 75 & Um & 17 & 0,12 \\
\hline 26 & Yemek & 31 & 0,21 & 76 & Yardım & 17 & 0,12 \\
\hline 27 & Zaman & 31 & 0,21 & 77 & Ancak & 16 & 0,11 \\
\hline 28 & $\mathrm{O}$ & 28 & 0,19 & 78 & İnsan & 16 & 0,11 \\
\hline 29 & Türkiye & 27 & 0,18 & 79 & Kişi & 16 & 0,11 \\
\hline 30 & Adam & 26 & 0,18 & 80 & Mutlaka & 16 & 0,11 \\
\hline 31 & Önemli & 25 & 0,17 & 81 & Televizyon & 16 & 0,11 \\
\hline 32 & Gün & 24 & 0,16 & 82 & Bazı & 15 & 0,10 \\
\hline 33 & Nasıl & 24 & 0,16 & 83 & Biri & 15 & 0,10 \\
\hline 34 & Kadar & 23 & 0,16 & 84 & Çocuk & 15 & 0,10 \\
\hline 35 & Plastik & 23 & 0,16 & 85 & Değil & 15 & 0,10 \\
\hline 36 & Sağlıklı & 23 & 0,16 & 86 & Dikkat & 15 & 0,10 \\
\hline 37 & Birçok & 22 & 0,15 & 87 & Efendim & 15 & 0,10 \\
\hline 38 & Kan & 22 & 0,15 & 88 & Ĕ̆ger & 15 & 0,10 \\
\hline 39 & Türk & 22 & 0,15 & 89 & İlgili & 15 & 0,10 \\
\hline 40 & İstanbul & 21 & 0,14 & 90 & Kaza & 15 & 0,10 \\
\hline 41 & $\mathrm{Mi}$ & 21 & 0,14 & 91 & Kutlu & 15 & 0,10 \\
\hline 42 & Sen & 21 & 0,14 & 92 & Küçük & 15 & 0,10 \\
\hline 43 & Diye & 20 & 0,14 & 93 & Peki & 15 & 0,10 \\
\hline 44 & Et & 20 & 0,14 & 94 & Sana & 15 & 0,10 \\
\hline
\end{tabular}




\begin{tabular}{llllllll}
\hline 45 & Güzel & 20 & 0,14 & 95 & Uygun & 15 & 0,10 \\
46 & İnsan & 20 & 0,14 & 96 & Üç & 15 & 0,10 \\
47 & İste & 20 & 0,14 & 97 & Büyük & 14 & 0,10 \\
48 & Son & 20 & 0,14 & 98 & Gelen & 14 & 0,10 \\
49 & Trafik & 20 & 0,14 & 99 & Gerek & 14 & 0,10 \\
50 & Ya & 20 & 0,14 & 100 & İçinde & 14 & 0,10 \\
\hline
\end{tabular}

Türkçeye yolculuk YDTÖ B1 düzeyi ders kitabı derlem tabanlı incelenerek ders kitabı bünyesinde en sık kullanılan 500 kelime (token) tespit edilmiş; Aksan vd. (2017) tarafından yayımlanan A Frequency Dictionary of Turkish (Türkçe Sıklık Sözlüğü) isimli çalışmada sık kullanıldığı tespit edilen ilk 500 kelime ile karşılaştırılmıştır. Bu bağlamda incelenen ders kitabından en sık kullanılan 500 kelime ile Aksan'ın (2017) yapmış olduğu çalışmada Türkçede en sık kullanılan 500 kelimenin kıyaslanması sonucunda 259 kelimenin ortak olduğu tespit edilmiştir. Oransal olarak değerlendirildiğinde Türkçede en sık kullanılan 500 kelime ile Türkçeye Yolculuk YDTÖ B1 düzeyi ders kitabında en sık kullanılan 500 kelime arasında \% 52'lik bir benzerlik olduğu tespit edilmiştir.

Tablo 2'de Türkçeye Yolculuk B1 düzeyi ders kitabında en sık kullanılan kelimelerin frekans değeri ve veri setindeki yaygınlık düzeyleri gösterilmiştir.

Türkçeye Yolculuk B1 düzeyi ders kitabının söz varlığı ve en sık kullanılan 100 kelime incelendiğinde

\section{B1 Düzeyi öğrencilerin yazılı söz varlığına yönelik bulgular}

Tablo 4. B1 Düzeyi Öğrencilerin Yazılı Söz Varlığına Yönelik Bulgular

\begin{tabular}{lll}
\hline $\begin{array}{l}\text { Toplam Kelime sayısı } \\
\text { (Token) }\end{array}$ & $\begin{array}{l}\text { Farklı Kelime } \\
\text { Sayısı(Type) }\end{array}$ & Kelime Hazine Katsayısı(Type/Token) \\
\hline 36074 & 10152 & 0,2814 \\
\hline
\end{tabular}

B1 düzeyinde Türkçe öğrenen öğrencilere 7 farklı konuda yazdırılan kompozisyonlar ve bu kompozisyonlardan oluşan veri seti incelenmiştir. Bu bağlamda kompozisyonlardan oluşan yazılı söz varlığının veri seti (token) 36704 kelimeden oluştuğu tespit edilmiştir. B1 düzeyi öğrencilerin yazılı söz varlığında farklı kelime sayısı (type) ise 10152 olarak saptanmıştır. Toplam kelime sayısının farklı kelime sayısına oranı 0.2814 ya da \% 28 olarak ifade edilebilir. Bu verilerden hareketle öğrencilerin yazılı söz varlığında her 100 kelimeden 28'sinin farklı olduğu tespit edilmiştir

Tablo 5’te B1 düzeyinde Türkçe öğrenen öğrencilerin yazdıkları kompozisyonlardan faydalanılarak oluşturulan veri setinde en sık kullanılan kelimelerin frekans değeri ve veri setindeki yaygınlık düzeyleri gösterilmiştir.

Tablo 5. B1 Düzeyi Öğrencilerin Yazılı Söz Varlığında En Sık Kullanılan Kelimeler

\begin{tabular}{llllllll}
\hline No & Kelime & Frekans & $\mathbf{\%}$ & No & Kelime & Frekans & \% \\
\hline 1 & Ve & 1336 & 3,68 & 51 & Mesela & 69 & 0,19 \\
2 & Bir & 707 & 1,95 & 52 & Hiç & 68 & 0,19 \\
3 & Çok & 620 & 1,71 & 53 & Ayrıca & 67 & 0,18 \\
4 & Bu & 595 & 1,64 & 54 & Başka & 67 & 0,18 \\
\hline
\end{tabular}




\begin{tabular}{|c|c|c|c|c|c|c|c|}
\hline 5 & İçin & 477 & 1,31 & 55 & Fazla & 67 & 0,18 \\
\hline 6 & $\mathrm{De}$ & 345 & 0,95 & 56 & Önce & 66 & 0,18 \\
\hline 7 & Her & 269 & 0,74 & 57 & $\mathrm{Ya}$ & 66 & 0,18 \\
\hline 8 & $\mathrm{Da}$ & 245 & 0,68 & 58 & Değil & 65 & 0,18 \\
\hline 9 & Çünkü & 231 & 0,64 & 59 & Veya & 63 & 0,17 \\
\hline 10 & Ama & 218 & 0,60 & 60 & Yani & 61 & 0,17 \\
\hline 11 & Daha & 212 & 0,58 & 61 & Bazen & 60 & 0,17 \\
\hline 12 & En & 204 & 0,56 & 62 & Şeyler & 59 & 0,16 \\
\hline 13 & Var & 200 & 0,55 & 63 & $\mathrm{Biz}$ & 58 & 0,16 \\
\hline 14 & Sonra & 199 & 0,55 & 64 & Korona & 58 & 0,16 \\
\hline 15 & $\mathrm{O}$ & 170 & 0,47 & 65 & Olmasaydı & 58 & 0,16 \\
\hline 16 & İyi & 166 & 0,46 & 66 & Düğün & 57 & 0,16 \\
\hline 17 & $\mathrm{Ne}$ & 165 & 0,45 & 67 & Yüzden & 57 & 0,16 \\
\hline 18 & Şey & 161 & 0,44 & 68 & Beni & 56 & 0,15 \\
\hline 19 & Ben & 148 & 0,41 & 69 & Evde & 56 & 0,15 \\
\hline 20 & Şimdi & 142 & 0,39 & 70 & Herkes & 56 & 0,15 \\
\hline 21 & Zaman & 134 & 0,37 & 71 & İnsan & 55 & 0,15 \\
\hline 22 & Bir & 130 & 0,36 & 72 & İş & 55 & 0,15 \\
\hline 23 & Kadar & 119 & 0,33 & 73 & Kolay & 53 & 0,15 \\
\hline 24 & Teknoloji & 117 & 0,32 & 74 & Olurdu & 53 & 0,15 \\
\hline 25 & Türkiye & 110 & 0,30 & 75 & Onun & 53 & 0,15 \\
\hline 26 & Eğitim & 108 & 0,30 & 76 & Olacak & 52 & 0,14 \\
\hline 27 & Nasıl & 108 & 0,30 & 77 & Sağlık & 50 & 0,14 \\
\hline 28 & İnsanlar & 103 & 0,28 & 78 & Bizim & 49 & 0,14 \\
\hline 29 & Ĕ̆gr & 101 & 0,28 & 79 & Eskiden & 49 & 0,14 \\
\hline 30 & Gibi & 101 & 0,28 & 80 & İlk & 49 & 0,14 \\
\hline 31 & Hem & 95 & 0,26 & 81 & Allah & 48 & 0,13 \\
\hline 32 & Zor & 93 & 0,26 & 82 & Ancak & 48 & 0,13 \\
\hline 33 & Olarak & 91 & 0,25 & 83 & Meslek & 48 & 0,13 \\
\hline 34 & Benim & 90 & 0,25 & 84 & Güzel & 47 & 0,13 \\
\hline 35 & Önemli & 89 & 0,25 & 85 & Hayat & 47 & 0,13 \\
\hline 36 & Büyük & 84 & 0,23 & 86 & Para & 47 & 0,13 \\
\hline 37 & Gün & 83 & 0,23 & 87 & Damat & 46 & 0,13 \\
\hline 38 & $\mathrm{Ki}$ & 82 & 0,23 & 88 & Fakat & 46 & 0,13 \\
\hline 39 & Tüm & 82 & 0,23 & 89 & Şu & 46 & 0,13 \\
\hline 40 & Bazı & 80 & 0,22 & 90 & $\mathrm{Az}$ & 45 & 0,12 \\
\hline 41 & İle & 79 & 0,22 & 91 & Vardır & 45 & 0,12 \\
\hline 42 & Bana & 77 & 0,21 & 92 & Kötü & 44 & 0,12 \\
\hline 43 & Yok & 75 & 0,21 & 93 & Neden & 43 & 0,12 \\
\hline 44 & Olan & 74 & 0,20 & 94 & Devam & 42 & 0,12 \\
\hline
\end{tabular}




\begin{tabular}{llllllll}
\hline 45 & Içın & 72 & 0,20 & 95 & Hatta & 42 & 0,12 \\
46 & Aynı & 71 & 0,20 & 96 & İyi & 42 & 0,12 \\
47 & Sadece & 71 & 0,20 & 97 & Zamanda & 42 & 0,12 \\
48 & Farklı & 70 & 0,19 & 98 & İnsanlar & 41 & 0,11 \\
49 & Oldu & 70 & 0,19 & 99 & Şekil & 41 & 0,11 \\
50 & Olmak & 70 & 0,19 & 100 & Ülke & 40 & 0,11 \\
\hline
\end{tabular}

B1 düzeyi öğrencilerin yazılı söz varlı̆̆ı derlem tabanlı incelenerek en sık kullanılan 500 kelime (token) tespit edilmiş; Aksan vd. (2017) tarafından yayımlanan A Frequency Dictionary of Turkish (Türkçe Sıklık Sözlüğü) isimli çalışmada sık kullanıldığı tespit edilen ilk 500 kelime ile karşılaştırılmıştır. Bu bağlamda B1 düzeyi öğrencilerin yazılı söz varlığında en sık kullanılan 500 kelime ile Aksan'ın (2017) yapmış olduğu çalışmada Türkçede en sık kullanılan 500 kelimenin kıyaslanması sonucunda 271 kelimenin ortak olduğu tespit edilmiştir. Oransal olarak değerlendirildiğinde Türkçede en sik kullanılan 500 kelime ile Türkçeye Yolculuk YDTÖ B1 düzeyi ders kitabında en sık kullanılan 500 kelime arasında \% 53'lük bir benzerlik olduğu tespit edilmiştir.

Tablo 3’te B1 düzeyinde Türkçe öğrenen bireylerin yazılı söz varlığında en sık kullanılan kelimelerin frekans değeri ve veri setindeki yaygınlık düzeyleri gösterilmiştir.

\section{Türkçeye Yolculuk B1 düzeyi ders kitabı ve B1 düzeyi öğrencilerin yazılı söz varlığında en sık kullanılan kelimelerin sözcük türleri bakımından değerlendirilmesi}

Araştırmanın bu aşamasında Türkçeye Yolculuk B1 düzeyi ders kitabının söz varlığı ve B1 düzeyinde Türkçe öğrenen öğrencilerin yazılı söz varlığı sözcük türleri açısından derlem tabanlı incelenmiş; en sık kullanılan 500 fiil, isim, sıfat tespit edilmiştir. Aksan'ın (2017) yapmış olduğu derlem tabanlı çalışmada en sık kullanılan 500 fiil, isim, sıfat listelenmiş B1 düzeyi öğrencilerin yazılı söz varlı̆̆ı ve B1 düzeyi YDTÖ ders kitabının söz varlığında en sık kullanılan 500 fiil, isim, sıfat ile karşılaştııılmış ve ortaklık düzeyleri tespit edilmiştir.

Tablo 6. B1 Düzeyi Öğrencilerin Yazılı Söz Varlı̆̆ı ve Türkçeye Yolculuk B1 Düzeyi Ders kitabının Söz varlığı ile Aksan'ın (2017) Sözcük Türlerine Göre Ortaklık Düzeyleri

\begin{tabular}{|c|c|c|c|c|}
\hline \multirow[t]{2}{*}{ Kelime Türleri } & \multicolumn{2}{|c|}{$\begin{array}{l}\text { Öğrencilerin Söz Varlığı ve Aksan } \\
\text { (2017) Ortaklık Düzeyi }\end{array}$} & \multicolumn{2}{|c|}{$\begin{array}{l}\text { Türkçeye Yolculuk B1 Ders Kitabı ve } \\
\text { Aksan(2017) Ortaklık Düzeyi }\end{array}$} \\
\hline & $f()$ & $\%$ & $f()$ & $\%$ \\
\hline Fiil & 215 & 43 & 195 & 38 \\
\hline Sifat & 175 & 35 & 160 & 32 \\
\hline İsim & 261 & 51 & 234 & 46 \\
\hline
\end{tabular}

Öğrencilerin yazılı söz varlığı ve Aksan'ın (2017) yapmış olduğu derlem tabanlı çalışmada en sık kullanılan 500 fiil, isim, sıfat kıyaslanmıştır. Bu çerçevede fiil türündeki kelimelerin benzerlik düzeyi ve frekans değeri \% 43 - 215; slfat türündeki kelimelerin benzerlik düzeyi ve frekans değeri \% 35 - 175; isim türündeki kelimelerin benzerlik düzeyi ve frekans değeri \% 51 - 261 olarak tespit edilmiştir.

Türkçeye Yolculuk B1 düzeyi YDTÖ ders kitabı ve Aksan'ın (2017) yapmış olduğu derlem tabanlı çalışmada en sık kullanılan 500 fiil, isim, sıfat kıyaslanmıştır. Bu çerçevede fiil türündeki kelimelerin 
B1 level textbooks of vocabulary, B1 level students of written vocabulary in terms of various variables based on review / R. Şimşek (pp. 152-171)

benzerlik düzeyi ve frekans değeri \% 38 - 195; ssfat türündeki kelimelerin benzerlik düzeyi ve frekans değeri \% 32 - 160; isim türündeki kelimelerin benzerlik düzeyi ve frekans değeri \% $46-234$ olarak tespit edilmiştir.

Fiil türündeki kelimelerin ortaklık düzeyinin öğrencilerin yazılı söz varlığında \% 43 olup B1 düzeyi ders kitabının söz varlığındaki \% 38'lik benzerlik düzeyinden daha yüksek olduğu ve öğrencilerin ders materyalinde kullanılandan daha fazla farklı fiil kullandığı tespit edilmiştir. Sıfat türündeki kelimelerin ortaklık düzeyinin öğrencilerin yazılı söz varlığında \% 35 olup B1 düzeyi ders kitabının söz varlığındaki \% 32'lik benzerlik düzeyinden daha yüksek olduğu ve öğrencilerin ders materyalinde kullanılandan daha fazla farklı sıfat kullandığı tespit edilmiştir. İsim türündeki kelimelerin ortaklık düzeyinin öğrencilerin yazılı söz varlığında \% 51 olup B1 düzeyi ders kitabının söz varlığındaki \% 46'lık benzerlik düzeyinden daha yüksek olduğu ve öğrencilerin ders materyalinde kullanılandan daha fazla farklı isim kullandığı tespit edilmiştir.

Öğrencilerin yazılı söz varlı̆̆ına isim, sıfat ve fillerin ders materyalinde kullanılan sözcük türlerine göre nicel olarak daha fazla olması sosyal çevre etkisi ve süreçte dili işlevsel kullanmaları ile ilişkilendirilebilir.

\section{Türkçeye Yolculuk B1 Düzeyi ders kitabı ve Bı düzeyi öğrencilerin söz varlığının kelime türlerine göre incelenmesi}

Öğrencilerin yazılı söz varlığı ve ders materyalinin söz varlığında en sık kullanılan ilk 50 isim Tablo 7’de gösterilmiştir.

Tablo 7. B1 Düzeyi Öğrencilerin Yazılı Söz Varlığı ve Türkçeye Yolculuk B1 Düzeyi Ders kitabının Söz varlığında En Sik kullanılan İsimler

\begin{tabular}{|c|c|c|c|c|c|}
\hline \multicolumn{3}{|c|}{ Öğrencilerin Yazılı Söz Varlığında En Sık Kullanılan İsimler } & \multicolumn{3}{|c|}{$\begin{array}{l}\text { Türkçeye Yolculuk YDTÖ Ders } \\
\text { Kitabının Söz Varlığında En Sık } \\
\text { Kullanılan İsimler }\end{array}$} \\
\hline No & Kelime & Frekans & No & Kelime & Frekans \\
\hline 1 & Şey & 295 & 1 & İş & 92 \\
\hline 2 & İnsan & 275 & 2 & Yer & 63 \\
\hline 3 & Hayat & 266 & 3 & İnsan & 54 \\
\hline 4 & Ülke & 251 & 4 & Zaman & 54 \\
\hline 5 & Zaman & 218 & 5 & Hayat & 52 \\
\hline 6 & Gün & 176 & 6 & Yemek & 52 \\
\hline 7 & Teknoloji & 150 & 7 & Çocuk & 48 \\
\hline 8 & Eğitim & 145 & 8 & $\mathrm{Ev}$ & 48 \\
\hline 9 & $\mathrm{Ev}$ & 139 & 9 & Konu & 46 \\
\hline 10 & Aile & 134 & 10 & Gün & 46 \\
\hline 11 & İş & 130 & 11 & Toplantı & 44 \\
\hline 12 & Meslek & 128 & 12 & Teknoloji & 43 \\
\hline 13 & Türkiye & 116 & 13 & Araç & 42 \\
\hline 14 & Arkadaş & 112 & 14 & Kaza & 40 \\
\hline 15 & Dünya & 110 & 15 & Kişi & 39 \\
\hline
\end{tabular}




\begin{tabular}{|c|c|c|c|c|c|}
\hline 16 & Neden & 105 & 16 & Adam & 38 \\
\hline 17 & Okul & 102 & 17 & Ülke & 36 \\
\hline 18 & Yer & 96 & 18 & Yll & 35 \\
\hline 19 & Yüz & 96 & 19 & Spor & 34 \\
\hline 20 & Yapay & 92 & 20 & Ülke & 33 \\
\hline 21 & Yemek & 75 & 21 & İç & 31 \\
\hline 22 & Kendi & 73 & 22 & Plastik & 30 \\
\hline 23 & Öğrenci & 67 & 23 & Film & 30 \\
\hline 24 & $\mathrm{Kuz}$ & 66 & 24 & Yan & 30 \\
\hline 25 & Ders & 65 & 25 & Baş & 29 \\
\hline 26 & Virüs & 64 & 26 & Yol & 27 \\
\hline 27 & Telefon & 64 & 27 & Neden & 27 \\
\hline 28 & Durum & 64 & 28 & Türkiye & 27 \\
\hline 29 & Anne & 64 & 29 & Saat & 27 \\
\hline 30 & Öğretmen & 63 & 30 & Trafik & 26 \\
\hline 31 & Kitap & 60 & 31 & Televizyon & 26 \\
\hline 32 & Sağlık & 59 & 32 & Türk & 26 \\
\hline 33 & Yol & 59 & 33 & Bilgi & 25 \\
\hline 34 & Para & 59 & 34 & Kitap & 25 \\
\hline 35 & Koro & 58 & 35 & Kendi & 25 \\
\hline 36 & Hastalık & 57 & 36 & Tiyatro & 24 \\
\hline 37 & Allah & 56 & 37 & Kan & 24 \\
\hline 38 & Üniversite & 54 & 38 & Oyun & 23 \\
\hline 39 & Konu & 54 & 39 & Vücut & 23 \\
\hline 40 & Sorun & 53 & 40 & Türkçe & 23 \\
\hline 41 & Hak & 53 & 41 & Yaş & 23 \\
\hline 42 & Yardım & 52 & 42 & Yardım & 23 \\
\hline 43 & Şekil & 52 & 43 & Kural & 22 \\
\hline 44 & Yll & 50 & 44 & Para & 22 \\
\hline 45 & Başkan & 48 & 45 & Söz & 22 \\
\hline 46 & İnternet & 48 & 46 & Sira & 22 \\
\hline 47 & Devlet & 48 & 47 & Telefon & 21 \\
\hline 48 & $\mathrm{El}$ & 46 & 48 & İstanbul & 21 \\
\hline 49 & Baba & 46 & 49 & Eşya & 20 \\
\hline 50 & İcat & 44 & 50 & Durum & 20 \\
\hline
\end{tabular}

Öğrencilerin yazılı söz varlığı ve ders materyalinin söz varlığında en sık kullanılan isimlere bakıldığında "İnsan, iş, aman, hayat, ülke, Türkiye, teknoloji” gibi isimlerin sık kullanıldığı saptanmıştır. Bu durumun oluşmasında dil kullanımının günlük yaşam ve ihtiyaçlarla ilgili olduğu söylenebilir. Ayrıca öğrencilerin kendi öncelikleri, ihtiyaçları çerçevesinde "meslek, yardım, üniversite, aile, öğrenci” isimlerini sık kullandıkları söylenebilir. 
B1 level textbooks of vocabulary, B1 level students of written vocabulary in terms of various variables based on review / R. Şimşek (pp. 152-171)

Öğrencilerin yazılı söz varlığı ve ders materyalinin söz varlığında en sık kullanılan ilk 50 sıfat Tablo 8'de gösterilmiştir.

Tablo 8. B1 Düzeyi Öğrencilerin Yazılı Söz Varlığı ve Türkçeye Yolculuk B1 Düzeyi Ders kitabının Söz varlı̆ında En Sik kullanılan Isimler

\begin{tabular}{|c|c|c|c|c|c|}
\hline \multicolumn{3}{|c|}{ Öğrencilerin Yazılı Söz Varlığında En Sık Kullanılan Sıfatlar } & \multicolumn{3}{|c|}{$\begin{array}{l}\text { Türkçeye Yolculuk Ydtö Ders } \\
\text { Kitabının Söz Varlığında En Sık } \\
\text { Kullanılan Sıfatlar }\end{array}$} \\
\hline No & Kelime & Frekans & No & Kelime & Frekans \\
\hline 1 & İyi & 166 & 1 & Küçük & 42 \\
\hline 2 & Zor & 93 & 2 & Güzel & 38 \\
\hline 3 & Önemli & 91 & 3 & İlk & 38 \\
\hline 4 & Büyük & 85 & 4 & İyi & 33 \\
\hline 5 & Aynı & 71 & 5 & Büyük & 31 \\
\hline 6 & Farklı & 70 & 6 & Böyle & 29 \\
\hline 7 & Başka & 67 & 7 & Bütün & 28 \\
\hline 8 & Fazla & 67 & 8 & Başka & 27 \\
\hline 9 & Kolay & 60 & 9 & Öyle & 26 \\
\hline 10 & Güzel & 52 & 10 & Yeni & 26 \\
\hline 11 & İlk & 49 & 11 & Uzun & 24 \\
\hline 12 & Kötü & 48 & 12 & Doğru & 24 \\
\hline 13 & Yeni & 46 & 13 & Biraz & 23 \\
\hline 14 & $\mathrm{Az}$ & 45 & 14 & Genç & 20 \\
\hline 15 & Bütün & 37 & 15 & Tek & 18 \\
\hline 16 & Sosyal & 36 & 16 & Tam & 18 \\
\hline 17 & Olumsuz & 33 & 17 & Son & 17 \\
\hline 18 & Uzun & 33 & 18 & Aynı & 17 \\
\hline 19 & Rahat & 32 & 19 & Kuyruklu & 15 \\
\hline 20 & Küçük & 32 & 20 & Yavaş & 15 \\
\hline 21 & Güçlü & 31 & 21 & Geç & 15 \\
\hline 22 & Olumlu & 31 & 22 & Yaşa & 15 \\
\hline 23 & Yardımcı & 30 & 23 & Çık & 14 \\
\hline 24 & Biraz & 29 & 24 & Fazla & 14 \\
\hline 25 & İlgili & 28 & 25 & İlgili & 13 \\
\hline 26 & Yüksek & 28 & 26 & Eski & 13 \\
\hline 27 & Uluslararası & 28 & 27 & Bol & 11 \\
\hline 28 & Tek & 28 & 28 & Önemli & 11 \\
\hline 29 & Böyle & 27 & 29 & Sağllklı & 10 \\
\hline 30 & Lazım & 25 & 30 & Hizlı & 10 \\
\hline 31 & Yakın & 24 & 31 & Ertesi & 10 \\
\hline 32 & Mutlu & 23 & 32 & Yaralı & 10 \\
\hline 33 & Popüler & 22 & 33 & Yaşlı & 10 \\
\hline
\end{tabular}




\begin{tabular}{llllll}
\hline 34 & Başarılı & 22 & 34 & Boş & 9 \\
35 & Uzak & 22 & 35 & Dolu & 9 \\
36 & İste & 22 & 36 & Sert & 9 \\
37 & Modern & 22 & 37 & Farklı & 9 \\
38 & Son & 21 & 38 & Âşı & 8 \\
39 & Kısa & 21 & 39 & Yakın & 8 \\
40 & Faydalı & 18 & 40 & Ağır & 8 \\
41 & Gerekli & 18 & 41 & Hazır & 8 \\
42 & Hızlı & 17 & 42 & Türlü & 8 \\
43 & Tabi & 17 & 43 & Zor & 8 \\
44 & Geleneksel & 17 & 44 & Sesli & 8 \\
45 & Eski & 17 & 45 & Mutlu & 8 \\
46 & Yabancı & 16 & 46 & Uçlu & 7 \\
47 & Ayrı & 16 & 47 & Tatlı & 7 \\
48 & Özel & 15 & 48 & Siyah & 7 \\
49 & Serbest & 14 & 49 & Açı & 7 \\
50 & Ünlü & 14 & 50 & Karşı & 7 \\
\hline
\end{tabular}

Öğrencilerin yazılı söz varlı̆̆ı ve ders materyalinin söz varlığında en sık kullanılan sıfatlar değerlendirildiğinde "iyi, güzel, büyük, küçük, farklı, aynı, yeni, eski” gibi sıfatların sık kullanıldığı tespit edilmiş; ayrıca bu sıfatların sıklık açısından benzer sıralamalara sahip olduğu saptanmıştır. "Başarılı, uluslararası, yabancı, popüler" sıfatları ders materyalinin söz varlığındaki sıfatlardan ayrışmaktadır. Bu durumda öğrencilerin farklı bir ülkede yaşıyor olmaları, ilgi alanları ve özettikleri amaçların etkili olduğu söylenebilir.

Öğrencilerin yazılı söz varlı̆̆ı ve ders materyalinin söz varlığında en sık kullanılan ilk 50 fiil Tablo 9'da gösterilmiştir.

Tablo 9. B1 Düzeyi Öğrencilerin Yazılı Söz Varlığı ve Türkçeye Yolculuk B1 Düzeyi Ders kitabının Söz varlı̆̆ında En Sik kullanılan İ̀simler

\begin{tabular}{llllll}
\hline \multicolumn{2}{c}{ Öğgrencilerin Yazılı Söz Varlığında En Sık Kullanılan Fiil } & \multicolumn{4}{l}{$\begin{array}{l}\text { Türkçeye Yolculuk YDTö Ders } \\
\text { Kultanın Söz Varlığında En Sık }\end{array}$} \\
\hline No & Kelime & Frekans & No & Kelime & Frekans \\
\hline 1 & Ol & 612 & 1 & Ol & 130 \\
2 & Yap & 275 & 2 & Et & 129 \\
3 & Et & 232 & 3 & Yap & 83 \\
4 & İste & 135 & 4 & Ver & 54 \\
5 & Çalış & 120 & 5 & İste & 52 \\
6 & Değil & 91 & 6 & Gel & 47 \\
7 & Ver & 86 & 7 & Başla & 35 \\
8 & Gel & 75 & 8 & Al & 35 \\
9 & De & 74 & 9 & De & 34
\end{tabular}

\footnotetext{
Adres $\mid$ Address 
B1 level textbooks of vocabulary, B1 level students of written vocabulary in terms of various variables based on review / R. Şimşek (pp. 152-171)

\begin{tabular}{|c|c|c|c|c|}
\hline 10 & Yaşa & 73 & 10 & Gerek \\
\hline 11 & Git & 72 & 11 & Var \\
\hline 12 & Bil & 68 & 12 & Git \\
\hline 13 & $\mathrm{Al}$ & 67 & 13 & Gör \\
\hline 14 & Kal & 61 & 14 & Bil \\
\hline 15 & Kullan & 53 & 15 & $\mathrm{Ye}$ \\
\hline 16 & Söyle & 51 & 16 & Kal \\
\hline 17 & Sev & 48 & 17 & Söyle \\
\hline 18 & Geliş & 46 & 18 & Çık \\
\hline 19 & Başla & 45 & 19 & Besle \\
\hline 20 & Düşün & 44 & 20 & Sağla \\
\hline 21 & $\mathrm{Geç}$ & 44 & 21 & Çalış \\
\hline 22 & $\mathrm{Ye}$ & 42 & 22 & Bul \\
\hline 23 & Gör & 41 & 23 & Geç \\
\hline 24 & Bul & 40 & 24 & Düşün \\
\hline 25 & Gerek & 39 & 25 & Kullan \\
\hline 26 & Yok & 38 & 26 & Konuş \\
\hline 27 & Değiş & 37 & 27 & Yaz \\
\hline 28 & Çık & 36 & 28 & Koy \\
\hline 29 & Oku & 33 & 29 & Bulun \\
\hline 30 & Öğren & 31 & 30 & Unut \\
\hline 31 & Giy & 26 & 31 & Ayrll \\
\hline 32 & Etki & 25 & 32 & Öğren \\
\hline 33 & Yaz & 25 & 33 & Bekle \\
\hline 34 & Sağla & 24 & 34 & Öl \\
\hline 35 & Getir & 22 & 35 & $\mathrm{Sev}$ \\
\hline 36 & Seç & 22 & 36 & Hazırla \\
\hline 37 & Konuş & 21 & 37 & Art \\
\hline 38 & Zorla & 20 & 38 & Getir \\
\hline 39 & Bulun & 20 & 39 & Bırak \\
\hline 40 & Bırak & 20 & 40 & Gir \\
\hline 41 & Bak & 19 & 41 & Tut \\
\hline 42 & Anlat & 19 & 42 & Uy \\
\hline 43 & Ulaş & 18 & 43 & Zor \\
\hline 44 & Çöz & 18 & 44 & Anla \\
\hline 45 & Özle & 17 & 45 & Yan \\
\hline 46 & Dur & 17 & 46 & Göster \\
\hline 47 & Anla & 16 & 47 & Kaybet \\
\hline 48 & Kolay & 15 & 48 & Yaşa \\
\hline 49 & Kur & 15 & 49 & Sor \\
\hline
\end{tabular}

\footnotetext{
Adres Address 
Öğrencilerin yazılı söz varlığı ve ders materyalinin söz varlığında en sık kullanılan fiiller değerlendirildiğinde "ol, et, yap, iste, gel, de, git" fiillerin sıralama bakımından benzer olduğu, hem öğrencilerin yazılı söz varlığı hem de ders materyalinin söz varlığında ortak olduğu tespit edilmiştir. "Geliş, öğren, çalış, oku, çalış" fiillerinin ders materyalinin söz varlı̆̆ının aksine daha üst sıralarda yer almasında öğrencilerin bireysel önceliklerinin etkili olduğu söylenebilir.

\section{Tartışma ve sonuç}

Yabancı dil olarak Türkçe öğretiminde söz varlığı ve sözcük öğretimi alanında yapılan çalışmalar çoğunlukla basılı materyallerin söz varlığına odaklanmaktadır (Arslan ve Durukan, 2014; Arslan, 2014; Aşık, 2007; Aydın, 2015; Bozkurt, 2015; Çelik, 2014; Tunçel, 2011). Yabancı dil eğitiminde hangi kelimelerin öncelikle öğretileceğine yönelik bir standart oluşturulmalıdır. Bu kapsamda uluslararası anlamda standartlar gözetilerek çalışmalar yürütülmektedir. Özellikle hedef dilde en sık kullanılan kelimelerin öğretimi sürecin başarısı için vazgeçilmez öncelikler arasında yer almaktadır. Dil öğrenen bireyin öncelikleri hedef dilin öğrenildiği düzeye göre farklılaşmaktadır. Yabancı dil öğretiminde temel düzey ile ileri düzey arasında köprü görevi gören B1 (orta) düzey kuru kelime öğretimi ve dilin işlevsel kullanımı adına "kritik dönem" olarak nitelenebilir. Bu çalışma da ifade edilen öncelikler, standartlar çerçevesinde derlem tabanlı yöntem benimsenmiş; öğrencilerin yazılı söz varlığı ile derste kullanılan materyalin okuma metinlerinin söz varllğı 1 analiz edilmiştir. B1 düzeyinde öğrencilerin yazılı söz varlığında ve öğretim sürecinde kullanılan ders materyalinin söz varlığında en sık kullanılan 500 kelime tespit edilmiş; Aksan vd (2017) tarafından derlem tabanlı olarak yürütülen en geniş kapsamlı çalışma unvanına sahip sıklık listesi ile karşılaştırılmıştır.

Şekil. B1 Düzeyi Öğrenciler ve Ders Materyaline Yönelik Veriler

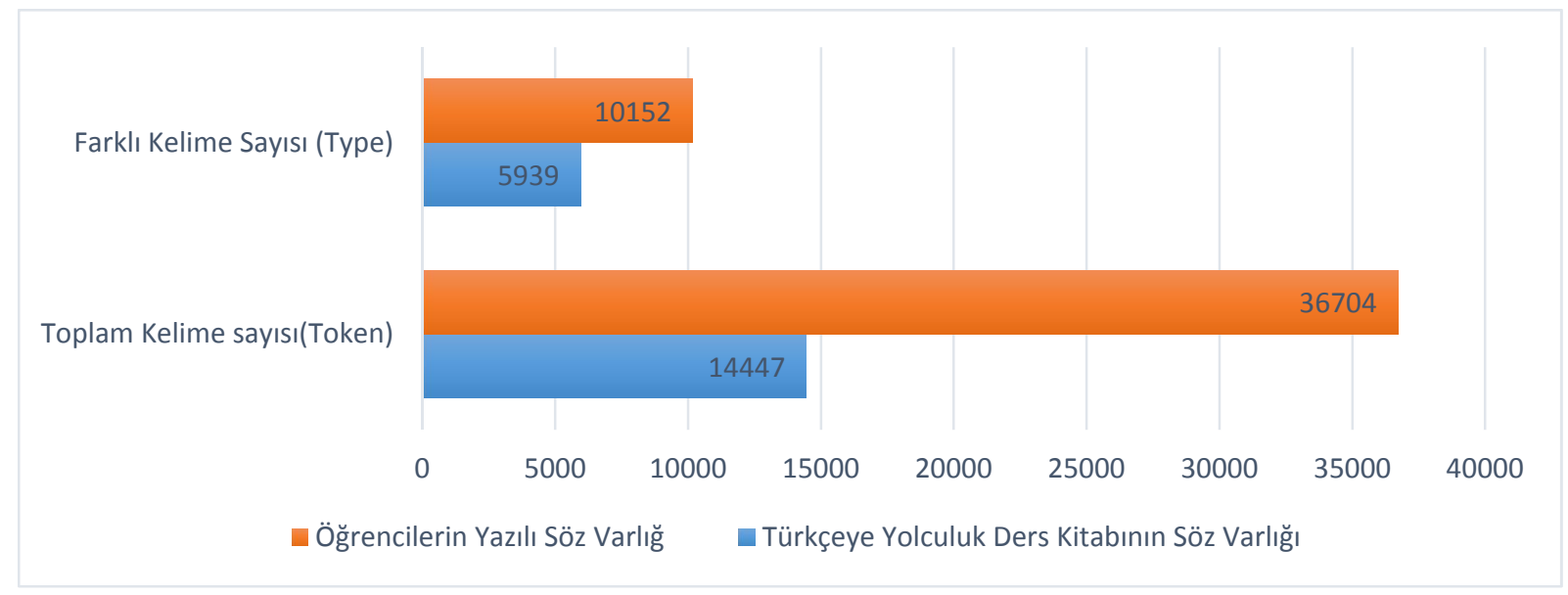

B1 düzeyinde Türkçe öğrenen öğrencilerin yazılı anlatımlarının söz varlığı incelenmiştir. Bu bağlamda Türkçe öğrenen öğrencilerin yazılı anlatımlarımdan oluşan veri setinin söz varlı̆̆ının (token) 36704 kelimeden; farklı kelime sayısının (type) ise 10152 kelimeden oluştuğu saptanmıştır. Toplam kelime sayısının farklı kelime sayısına oranı 0.2814 ya da \% 28 olarak tespit edilmiştir. Bu yönü ile B1 düzeyinde Türkçe öğrenen öğrencilerin yazılı söz varlığında kelime hazine katsayısının (type/token) Türkçeye Yolculuk B1 düzeyi ders kitabındaki kelime hazine katsayısına göre oldukça geride kaldığı görülmektedir. 
B1 level textbooks of vocabulary, B1 level students of written vocabulary in terms of various variables based on review / R. Şimşek (pp. 152-171)

Şekil. B1 Düzeyi Öğrencilerin Yazılı Söz varlığı ve Ders Materyalinin Söz Varlığında Type/Token Oranı

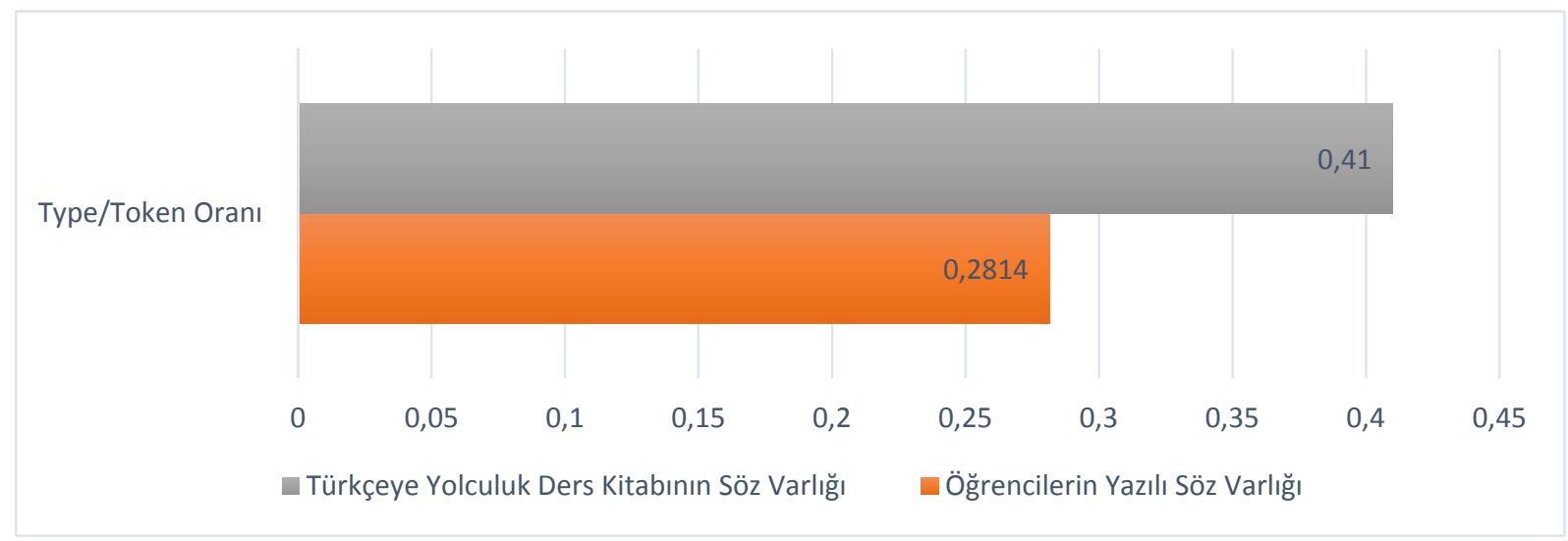

Çalışma çerçevesinde incelenen Türkçeye Yolculuk B1 düzeyi ders kitabı ve çalışma kitabında 60 metin incelenmiş; bu metinlerin söz varlığı (token) 14447 kelime; farklı kelime sayısının (type) ise 5939 olduğu tespit edilmiştir. Toplam kelime sayısının farklı kelime sayısına oranı (type/token) o.41 ya da \% 41 olarak ifade edilebilir. Bu verilerden hareketle ders kitabı bünyesinde her 100 kelimeden 41'inin farklı olduğu tespit edilmiştir. Tüm kelimelerin farklı kelimelere oranı (type/token) gözetildiğinde ders materyalinin type/token oranının daha yüksek olduğu saptanmıştır.

Araştırmanın ikinci aşamasında Türkçeye Yolculuk ders kitabında yer alan okuma metinlerinin söz varlığı ve öğrencilerin yazılı anlatımlarının söz varlığı derlem tabanlı incelenmiş; en sık kullanılan 500 kelime (token) bilgisayar yazılımı aracılığı ile tespit edilmiş; Aksan vd. (2017) tarafından yayımlanan A Frequency Dictionary of Turkish (Türkçe Sıklık Sözlüğü) isimli çalışmada sık kullanıldığı tespit edilen ilk 500 kelime ile karşılaştırılmıştır. Bu bağlamda incelenen ders kitabında yer alan okuma metinlerinde en sık kullanılan 500 kelime ile Aksan'ın (2017) yapmış olduğu çalışmada Türkçede en sık kullanılan 500 kelimenin kıyaslanması sonucunda 259 kelimenin ortak olduğu; oransal olarak değerlendirildiğinde Türkçede en sık kullanılan 500 kelime ile Türkçeye Yolculuk YDTÖ B1 düzeyi ders kitabında en sık kullanılan 500 kelime arasında \% 52'lik bir benzerlik olduğu tespit edilmiştir.

B1 düzeyi öğrencilerin yazılı söz varlığında en sık kullanılan 500 kelime ile Aksan'ın (2017) yapmış olduğu çalışmada Türkçede en sık kullanılan 500 kelimenin kıyaslanması sonucunda 271 kelimenin ortak olduğu; oransal olarak değerlendirildiğinde Türkçede en sık kullanılan 500 kelime ile Türkçeye Yolculuk YDTÖ B1 düzeyi ders kitabında en sık kullanılan 500 kelime arasında \% 53'lük bir benzerlik olduğu tespit edilmiştir. Öğrencilerin yazılı söz varlı̆̆ı ve ders materyalinde bulunan okuma metinlerinin söz varlı̆̆ı Aksan (2017) derlem tabanlı çalışması açısından birbirine yakın düzeyde ortak kelime içerdiği tespit edilmiştir.

Araştırmanın son aşamasında ders materyalinde yer alan okuma metinlerinin ve öğrencilerin yazılı anlatımlarının söz varlığı sözcük türleri bakımından derlem tabanlı incelenmiştir. Bu bağlamda Aksan vd (2017) çalışmada en sık kullanılan 500 isim, sıfat ve fiil ile öğrencilerin yazılı anlatımının ve ders materyalinde yer alan okuma metinlerinin söz varlığında en sık kullanılan 500 isim, sıfat ve fiil karşılaştırılmış; benzerlik düzeyleri tespit edilmiştir. 
Şekil. B1 Düzeyi Öğrencilerin Yazılı Söz Varlığı ve Türkçeye Yolculuk B1 Düzeyi Ders kitabının Söz varlığı ile Aksan'ın (2017) Sözcük Türlerine Göre Ortaklık Düzeyi

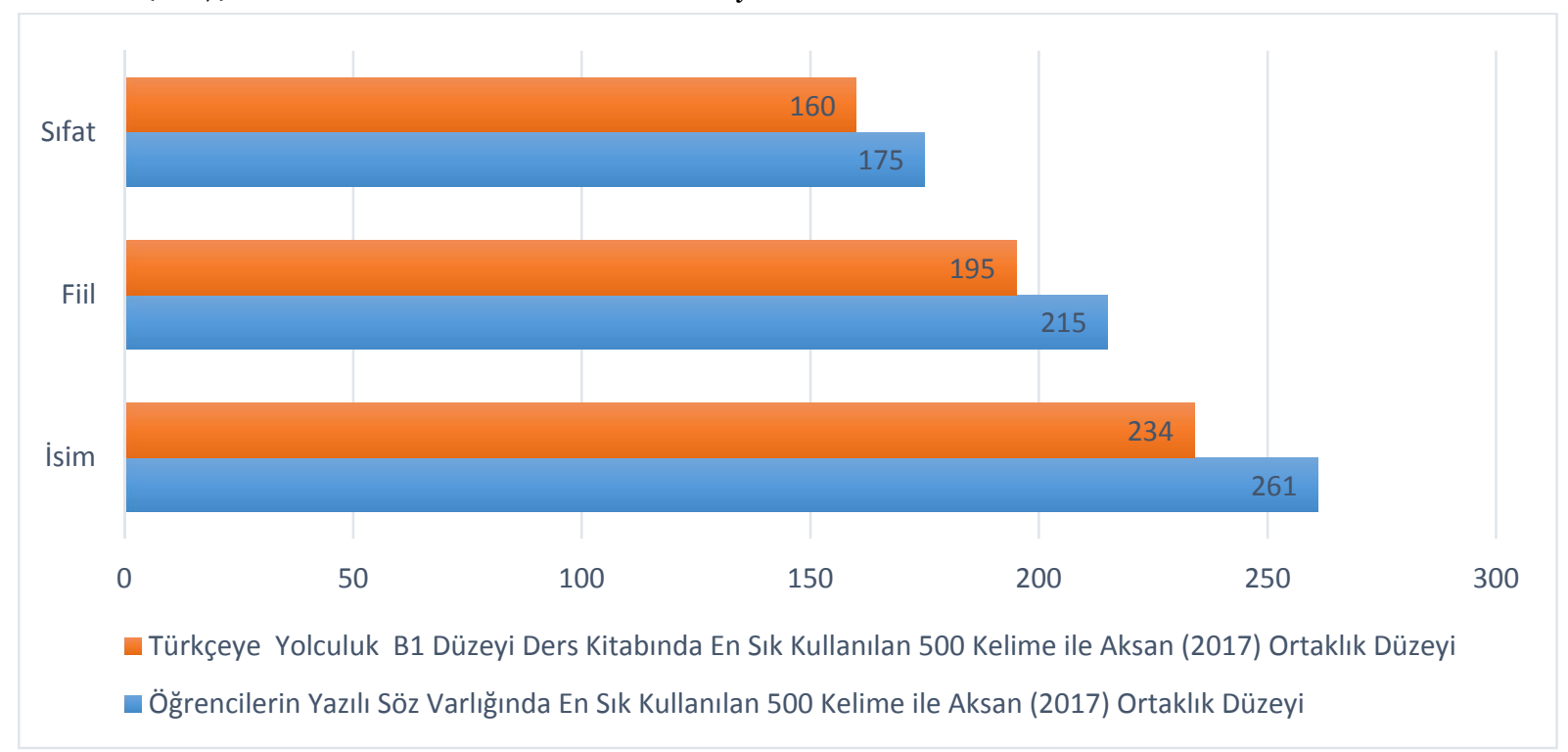

Öğrencilerin yazılı söz varlığı ve Aksan’ın (2017) yapmış olduğu derlem tabanlı çalışmada en sik kullanılan fiil türündeki kelimelerin benzerlik düzeyi ve frekans değeri \% 43 - 215; sıfat türündeki kelimelerin benzerlik düzeyi ve frekans değeri \% 35 - 175; isim türündeki kelimelerin benzerlik düzeyi ve frekans değeri \% 51 - 261 olarak tespit edilmiştir.

Türkçeye Yolculuk B1 düzeyi YDTÖ ders kitabı ve Aksan'ın (2017) yapmış olduğu derlem tabanlı çalışmada en sık kullanılan fiil türündeki kelimelerin benzerlik düzeyi ve frekans değeri \% 38 - 195; sıfat türündeki kelimelerin benzerlik düzeyi ve frekans değeri \% $32-160$; isim türündeki kelimelerin benzerlik düzeyi ve frekans değeri \% 46 - 234 olarak tespit edilmiştir.

Öğrencilerin yazılı söz varlı̆̆ı ve ders materyalinin söz varlığında en sık kullanılan isimlere bakıldığında “İnsan, iş, aman, hayat, ülke, Türkiye, teknoloji” gibi isimlerin sık kullanıldığı; Bu durumun oluşmasında dil kullanımının günlük yaşam ve ihtiyaçlarla ilgili olduğu ifade edilebilir.

Öğrencilerin yazılı söz varlığı ve ders materyalinin söz varlığında en sık kullanılan sıfatlar değerlendirildiğinde "iyi, güzel, büyük, küçük, farklı, aynı, yeni, eski” gibi sıfatların sık kullanıldığı tespit edilmiş; ayrıca bu sıfatların sıklık açısından benzer sıralamalara sahip olduğu saptanmıştır. "Başarılı, uluslararası, yabancı, popüler" sıfatları ders materyalinin söz varlığındaki sıfatlardan ayrışmaktadır. Bu durumda öğrencilerin farklı bir ülkede yaşıyor olmaları, ilgi alanları ve özettikleri amaçların etkili olduğu söylenebilir.

Öğrencilerin yazılı söz varlığı ve ders materyalinin söz varlığında en sık kullanılan fiiller değerlendirildiğinde "ol, et, yap, iste, gel, de, git" fiillerin sıralama bakımından benzer olduğu, hem öğrencilerin yazllı söz varlığı hem de ders materyalinin söz varlığında ortak olduğu tespit edilmiştir. "Geliş, öğren, çalış, oku, çalış" fiillerinin ders materyalinin söz varlığının aksine daha üst sıralarda yer almasında öğrencilerin bireysel önceliklerinin etkili olduğu söylenebilir.

Öğrencilerin yazılı anlatımının söz varlığı ve derslerde kullanılan Türkçeye Yolculuk B1 düzeyi ders kitabının söz varlığı Derlem tabanlı incelenmiş; Aksan vd (2017) çalışması ile karşılaştırılmıştır. 
B1 level textbooks of vocabulary, B1 level students of written vocabulary in terms of various variables based on review / R. Şimşek (pp. 152-171)

Derlem tabanlı yapılan bu çalışmanın Türkçe için en geniş çaplı ve gösterge kaynak olduğu düşünüldüğünde en sık kullanılan 500 kelimeye yönelik ortaklık düzeyinin ders materyalinde \% 52; öğrencilerin yazılı söz varlığında \% 53 gibi düşük bir düzeydedir. Bu bağlamda Türkçede en sık kullanılan kelimelerle ortaklık düzeyinin ders materyalinde en az \% 65 ve üzeri olması gerektiği söylenebilir. Ayrıca en sık kullanılan 500 sıfat, isim, ve fiil bakımından benzerlik düzeyinin de oldukça düşük olduğu görülmektedir. $\mathrm{Bu}$ benzerlik düzeylerinin öğrencilerin yazılı anlatımı ve dil kullanımlarını da etkileyeceği düşünüldüğünde ders materyallerinde kullanılan içeriklerin uluslararası standartlarda tekrar gözden geçirilmesi; söz varlığının derlem tabanlı olarak yapılandırılmasına yönelik gereklilik belirginleşmektedir. Yapılan çalışmaya benzer mahiyette, farklı düzeylerde daha geniş kapsamlı çalışmaların yapılması alan yazın açısından da oldukça faydalı olacaktır.

\section{Kaynakça}

Akpınar Dellal N. ve Seyhan Yücel M. (2015). Yabancı dil öğretmenlerinin derslerinde materyal kullanımına ilișkin tutum ve görüssleri. Turkish Studies International Periodical For The Languages, Literature and History of Turkish or Turkic, 10(2), 1051-1066. http://dx.doi.org/10.7827/TurkishStudies.7950.

Akgül, A., Demirer, N., Gürcan, E., Karadaş, D., Karahan, İ. ve Uysal, A. (2018). Ortaokul ve imam hatip ortaokulu türkçe 7. sinıf ders kitabı. Ankara: Millı̂ Eğitim Bakanlığı Yayınları.

Aksan, D. (1977). Her Yönüyle Dil (Vol. 1). Türk Dil Kurumu Yayınları.

Aksan, D. (2014a). Anadilimizin söz denizinde (3. Basım). Ankara: Bilgi Yayınevi.

Aksan, D. (2014b). Türkçenin zenginlikleri incelikleri (4. basım). Ankara: Bilgi Yayınevi.

Aksan, D. (2015). Türkçenin sözvarhı̆ı (birinci basım). Ankara: Bilgi Yayınevi.

Aksan, D. (2017). Türkçenin gücü (15. basım). Ankara: Bilgi Yayınevi.

Aksan, Y., Aksan, M., Mersinli, Ü. ve Demirhan, U. U. (2017). A frequency dictionary of Turkish. London and New York: Routledge.

Aksan, Y. ve Demirhan, U. U. (2015). Genel adlar: Sıklık listesinden işlevsel ulamlara. 28. Ulusal Dilbilim Kurultayı Bildiri Kitabı, 3-17. Ankara: Ayrıntı Basım Yayın ve Matbaacılık.

Arslan, N. (2014). Yabancılara Türkçe Öğretimi Ders Kitaplarında Söz Varlığı Unsurlarının İncelenmesi. Yayınlanmamış Yüksek Lisans Tezi, Trabzon: Karadeniz Teknik Üniversitesi Eğitim Bilimleri Enstitüsü

Arslan, N., Durukan, E. (2014). Yabancılara Türkçe Öğretimi Ders Kitaplarında Söz Varlığı Unsurlarının İncelenmesi. International Journal of Language Academy, 2(4), 247-265.

Aşık, U. (2007). Yabancılar İçin Temel Türkçe Sözcük Varlığının Oluşturulması. Yayınlanmamış Yüksek Lisans Tezi, İzmir: Dokuz Eylül Üniversitesi Ĕ̆itim Bilimleri Enstitüsü.

Aydın, M. (2015). Yabancı Dil Olarak Türkçe Öğretiminde Kullanılan Ders ve Okuma Kitaplarındaki Kelime Sıklı̆̆ı ve Seviyelere Göre Sözcük Hazinesi Çalışması. Yayınlanmamış Yüksek Lisans Tezi, Ankara: Gazi Üniversitesi Eğitim Bilimleri Enstitüsü.

Baş, B. (2011). Söz varlığı ile ilgili çalışmalarda kullanılacak ölçütler. Türklük Bilimi Araştırmaları, 29(29), 27-61.

Bozkurt, B. (2015). Türkçenin Yabancı Dil Olarak Öğretiminde Orta Seviye (B1-B2 Düzeyi) Hedef Sözcük Belirleme Çalışması. Yayınlanmamış Yüksek Lisans Tezi, İstanbul: Marmara Üniversitesi Eğitim Bilimleri Enstitüsü

Coxhead, A. (2000). 'A New Academic Word List.' TESOL Quarterly 34:2, 2000: 213-238.

Çelik, S. (2014). Yabancı Dil Olarak Almanca ve Türkçe Öğretimi A1 ve A2 Seviyesindeki Ders Kitaplarında Kullanılan Söz Varlığının Karşılaştırılması. Yayınlanmamış Yüksek Lisans Tezi, İstanbul: Marmara Üniversitesi Eğitim Bilimleri Enstitüsü. 
Dash, N. S. (2008). Corpus linguistics: An introduction. Pearson Education India.

Demirel, Ö. ; Kıroğlu, K. (2005), Konu Alanı Ders Kitabı İnceleme, Pegema Yayıncılık, Ankara

Elena, T. B. (2001). Corpus linguistics at work. Studies in Corpus Linguistics, John Benjamins Publishing Company, Amsterdam and Philadelphia

Grabe, W. (1991). Current developments in second language reading research. TESOL Quarterly, 25(3), 375-406.

Gries, S. T. (2016). Quantitative corpus linguistics with R: A practical introduction. Taylor \& Francis.

Göçen, G., \& Alpaslan, O. K. U. R. (2017). Türkçeyi yabancı dil olarak öğrenenlerin yazılı anlatımlarındaki sözcüklerin kullanım sıklğı. Erzincan Üniversitesi Ĕ̆itim Fakültesi Dergisi, 19(3), 119-136.

Karadağ, Ö. (2019). Aynı Sınıf düzeyi için hazırlanan Türkçe ders kitaplarının ortak sözvarlı̆̆ı açısından karşılaştırılması. Ana Dili Ĕgitimi Dergisi, 7(4), 1130-1140.

Karasar, N. (2010). Bilimsel araştırma yöntemi. Ankara: Nobel Yayınları

Karatay, H. (2007). Kelimesözcük öğretimi. Gazi Üniversitesi Gazi Eğitim Fakültesi Dergisi, 27(1), 141-153.

Karatay, H. (2020). Türkçenin yabancı dil olarak öğretiminde söz varlığı ve geliştirilmesi. H. Karatay (Ed.), Türkçenin Yabancı Dil Olarak Öğretimi El Kitabı (s. 253-270). Ankara: Pegem Akademi Yayınları.

Kurudayığlu, M., \& Dölek, O. (2019). Söz varlığı ve sözcük öğretiminin önemi. Türkçenin Sözcük Öğretimi, 19-36.

Matsuoka, W., Hirsh, D. (2010). Vocabulary learning through reading: Does an ELT course book provide good opportunities?. Reading in a Foreign Language, 22(1), 56-70.

McEnery, T., Hardie, A. (2011). Corpus linguistics: Method, theory and practice. Cambridge University Press.

Özkan, B. (2010). Türkçenin öğretiminde sifatlarin eşdizim sözlüğü: yöntem ve uygulama.eUluslararası Ĕ̆itim Araştırmaları Dergisi, 1(2), 51-65.

Özkan, B. (2013). Yöntem ve uygulama açısından "Türkiye Türkçesi söz varlığının derlem tabanlı sözlüğü”. Bilig, 66, 149-178.

Sampson, Geoffrey and Diana McCarthy (2005). Corpus Linguistics: Reading in a Widening Discipline. New York: Continuum.

Tunçel, H. (2011). Yabancılara Türkçe Öğretiminde Sözlü Türkçenin Kelime Sıklı̆̆ı ve Yaygınlığını Belirleme Çalışması. Yayınlanmamış Yüksek Lisans Tezi, Çanakkale: Onsekiz Mart Üniversitesi Sosyal Bilimler Enstitüsü.

Weisser, M. (2016). Practical corpus linguistics: An introduction to corpus-based language analysis (Vol. 43). John Wiley \& Sons.

Yılmaz, T. ve Doğan, Y. (2014). 7. sınıf öğrencilerinin anlamını bilmedikleri kelimesözcükler ve Türkçe ders kitaplarındaki kelimesözcük çalışmaları bağlamında kelimesözcük öğretimi. Mustafa Kemal Üniversitesi Sosyal Bilimler Enstitüsü Dergisi, 11(25), 279-295. 